\title{
Overview Case Analysis Applied to Evaluate Technology Transfer Projects of a Mexican Public University
}

\author{
Vega-González, Luis Roberto ${ }^{1 *}$; Vega-Salinas, Roberto Misael ${ }^{2}$
}

\begin{abstract}
The objective of this work is to propose a rapid methodology called Overview Case Analysis (OCA) to analyze in a synthetic and simple form, the tremendous amount of information that is created through the years in a technology transfer project. Using OCA analyst can rapidly detect the project highlights along its critical path of the technology transfer project. At the end of the evaluation process, qualification of the project performance is performed using a coarse scale to measure the technology transfer capacity of the participant organizations. To prove the methodology proposed, we explore the economic and social impact results of some technology transfer projects developed by academic groups of the National Autonomous University of Mexico (UNAM, by its Spanish acronym). The conclusion is that in order to have a successful TTP, at least three conditions are necessary: (a) the project must be handled by an efficient technology transfer team ( $T^{3}$ ); (b) the technology transferred must be mature; and (c) the technology transferred must have economic and social impacts for the final organization or other users inside the receiver country.
\end{abstract}

Keywords: technology; transfer; projects; rapid evaluation.

Submitted: March $28^{\text {th }}, 2018$ / Approved: August $14^{\text {th }}, 2018$

\section{Introduction}

In a technology transfer project at least two parts participate, the organization that owns and transfers the technology and the organization who receives it. Both parts must establish a human intellectual capital team who must play many roles as investors, administrators, technologists, technicians and sponsors, among others. Each part also requires the investment of important quantities of money, time and effort. Since this is an intense intercommunication process, it is well known that there are many problems for efficient technology transfer; a frequent one is that stakeholders involved will not be equally motivated to use their resources to transfer technologies, if they perceive that they do not benefit fairly from such transfers. For that reason, the interchange terms must be clearly pointed out and must be negotiated in a range of different forms that goes from the selection of the appropriate payment terms, the interchange of technology-market via joint ventures up to technology interchange. Moreover, the success of a technology transfer project not only depends on the initial agreement terms, but also on some other human, technical, technological and economic variables that we are about to mention.

\section{Literature Review and reference framework}

Lets start by recognizing that technology is regarded as a key driver for global competitiveness and socio-economic development. For Kondo (2005, pp.155) it functions as the engine of growth. In a few words, technology transfer (TT) is a shortcut to development. It helps the late country entrants to reduce the technology gap quickly (ECOSOC, 2014; cited by Kundu et al, 2015). Likewise, technology transfer has been understood as a series of processes or mechanisms for the rapid transfer of essential core knowledge and skills from one country/region/firm to another. (Shrestha, 1995). Nevertheless, it is a complex process since many authors suggest that effective transfer occurs when technology is requested, transmitted, received, understood, applied, diffused widely and improved. (Ofori, 1994 and UNCTAD, 1990; cited by Shrestha, 1995).

In that sense, far from being a reality in the institutional context and the everyday development experience, technology transfer in developing countries is not well understood among entrepreneurs, academics politicians nor decision makers. However, the idea of the important link between technology transfer, economic development and the role of universities has arisen in practically all economic sectors of Latin-American developing countries.

Therefore, developing countries urgently need to build capabilities in developing and/or applying new technologies in order to enhance cost-effectiveness, make the best use of natural resources, and compete in international markets. (Beukman \& Steyn, 2011)

Today, in their struggle to survive, enterprises in developing countries are hurrying to keep abreast with technological advance (Awny, 2005). As the indigenous technological capabilities of developing countries are weak by default, they try to import technology internationally.

Experience has shown that in doing so, a number of obstacles might cause the technology acquisition process be less effective, or even sometimes, turns into a failure economically and/or technically; therefore, the technical and technological capacities of the human resources

(1) Centro de Ciencias Aplicadas y Desarrollo Tecnológico, Universidad Nacional Autónoma de México, Circuito Exterior S/N, Ciudad Universitaria, A.P.

70-186, Delegación Coyoacán, CP 04510, Ciudad de México.

(2) Facultad de Contaduría y Administración, UNAM, Circuito exterior s/n, Ciudad Universitaria, Ciudad de México.

*Corresponding author: 1rvg@unam.mx 
of the countries' organizations that receive technology are a decisive factor in a successful absorption and technology transfer. Kundu, et al, (2015) point out that the emphasis of the existing literature is on the extrinsic organization factors that affect technology transfer such as technology, market, finance, government, environment, culture and society, which depend on third parties and is beyond the scope and capabilities of transferor and transferee. They indicate that more emphasis is required on the study of the intrinsic factors such as goal compatibility, perceptional differences on technology and transfer, environmental differences as well as cultural differences, learning and unlearning, building capabilities, mastering change management, networking, and so on., to make the technology transfer successful.

Accordingly, Roy and Mehnen (2008) consider that continuous improvement of products and the introduction of completely new products are a day-to-day challenge that industry has to face to stay competitive in a dynamic market. They also point out that academia is one of the sources of novel and scientifically well-founded technologies. Furthermore, academia has a rich pool of thoroughly tested methods and well-educated students and professional academics to deliver these methods. Technology transfer between academia and industry, therefore, is a productive way to bridge the gap between 'mysterious' theory and 'plain' practice. Nonetheless, transferring a technology into a new environment means that this technology should be understandable and maintainable over a long time. For industrial applications, this implies training, consultancy and continuous updating of technology and therefore requires well-planned collaboration among participants. In these processes, engineers play a very significant role.

In the past, technology transfer processes occurred normally via local or regional collaborations. For Kondo (2005) today, the participation of developing countries in international networks for the acquisition of technology and to perform the large number of activities needed, ranging from obtaining foreign direct investment (FDI) up to licensing is important. In addition, technology assimilation and domestic diffusion is necessary for full use of acquired technology. Further, domestic networking between industry, universities and public research institutes is necessary to utilize all technological capability for industrial development.

Most technological progress in developing countries stems from the absorption and adaptation of existing technologies, rather than the invention of completely new technologies. Technologies can be sourced, assimilated, and adopted from all over the world to be utilized in high-value added production. In developing countries, technology transfer projects usually aim to introduce new techniques through investment in new plants, improving existing techniques, and generating new knowledge. (Afenyadu et al, 1999; Bischoff, 2003; Saad et al, 2002; World Bank, 2008; cited by Beukman \& Steyn, 2011, pp.49)

Technology is not static, but rather implies continuous innovation for increased profitability, growth, sustainability, and competitiveness. Transfer consists of (1) materials, final products, components, equipment, and plants; (2) designs, blueprints, and know-how to create the desired capability; and (3) know-why and information to innovate and to adapt existing technology. Transfer does not only mean knowledge movement from one entity to the next, but also encompasses exchange, cooperation, partnerships, and collaboration. (Beukman \& Steyn, 2011, pp.41)

In developing countries like Mexico, the portfolio of sourcing strategies available to a firm in order to access to new technology is: knowledge creation through internal R\&D departments, knowledge sharing with suppliers or market relationships, and also transfer from knowledge institutions such as public and private research centers. In this paper, we address the third case recognizing that public universities are a central source of knowledge, but we question the general belief that knowledge is per se flowing between the private and academic spheres through the conduct of university-Industry relationships. (Hermans \& Castiaux, 2007). As we will see in the cases overview, it is not always so simple.

Probably the main legal instrument of a technology transfer project $(T T P)$ is in most cases, the technology transfer agreement. Which is the legal instrument used in most countries to handover the intellectual property from the part that transfers technology to the one who receives it. Then an efficient TTP requires the understanding of the Intellectual Property System and the culture behind it.

In developing countries intellectual property culture is not a problem, Dummond (2015), indicates that since 1787, the US Congress gave to authors and inventors the exclusive right to commercially exploit their respective writings and discoveries. The Second World War catalyzed the growing role of American universities in creating intellectual property through the foundation in the 1970's of the Techno Science System in the USA. By 1978, the General Accounting Office reported that the US government owned 28,000 patents but commercialized less than $5 \%$ of them. To solve this problem, the Bayh-Dole Act was adopted in 1980, giving federally funded small businesses and universities the ownership of the patents they file. This led to the creation of Technology Transfer Offices (TTO's) at many universities. A similar system was adopted in México at the end of last century, currently the intellectual property results of technology development projects financed with public funds belongs to the public universities in which the developments were carried out. Nevertheless, the patenting culture is still incipient, in 2014 there were 16,135 patent applications, and only 9,819 conceded. Notably, $96 \%$ of the conceded patents correspond to foreign applicants.

If the heart of the TTP is the intellectual property the organization has, the body structure of it is the capability organizations have to adapt and perform a project management methodology. But certainly there must be a range of capabilities to perform TTP's that change from one organization to the other. The same organization could have TTP's with different levels of efficiency results. Sometimes it could depend on the directives and other stakeholders interest to have a successful project, in other cases financial resources available could be insufficient or the technical and intellectual capital available is not able to provide good results. 
The process of technology transfer is complex, and depends on a huge number of variables endogenous and exogenous to the organization, therefore it requires a particularly careful formation of multi and interdisciplinary work teams.

The United Nations Department of Economic and Social Affairs (UNDESA), has established a technology transfer framework specifically for climate change mitigation projects, clearly applicable to any kind of TTP. They have defined five key issues for meaningful and effective actions, as follows: (1) human resource development, (2) institutional development, (3) information development, (4) partnership and networking and, (5) collaborative Research and Development (R\&D).

UNDESA also found some barriers for technology transfer processes between organizations or individuals, which are: (1) market conditions, (2) the legal system, (3) the physical infrastructure, (4) social and political structures, (5) culture, (5) psychology. Finally, they propose that the framework for TTP requires five well-defined elements, which are: (1) recognition of technology needs and needs assessment;
(2) technology information; (3) enabling environment; (4) capacity building; and (5) mechanisms to facilitate institutional and financial support to technology transfer (UNDESA, 2008)

For Klingner (2008), technology transfer can be structured in three phases, namely: pre-transfer, transfer and post-transfer. The objective in pre-transfer is 'search and mutual identification'. The transferor and transferee will study and analyze the organizational goals, objectives, and strategic plan of each other to reach a common beneficial association.

The objective of the transfer stage is planning, transfer and implementation. At this stage, both transferor and transferee will study and act on (1) level of preparedness; (2) barrier analysis; (3) communication channel establishment; (4) trust building, (5) mode of technology transfer; (6) technology transfer agreement, (7) identification of critical activities; (8) implementation plan and project management; (9) building capabilities; (10) training; (11) managing conflicts; (12) review, feedback; and (13) risk analysis.

Figure 1 Activities for a Technology Transfer Project (TTP). Modified from Beukman \& Steyn (2011)

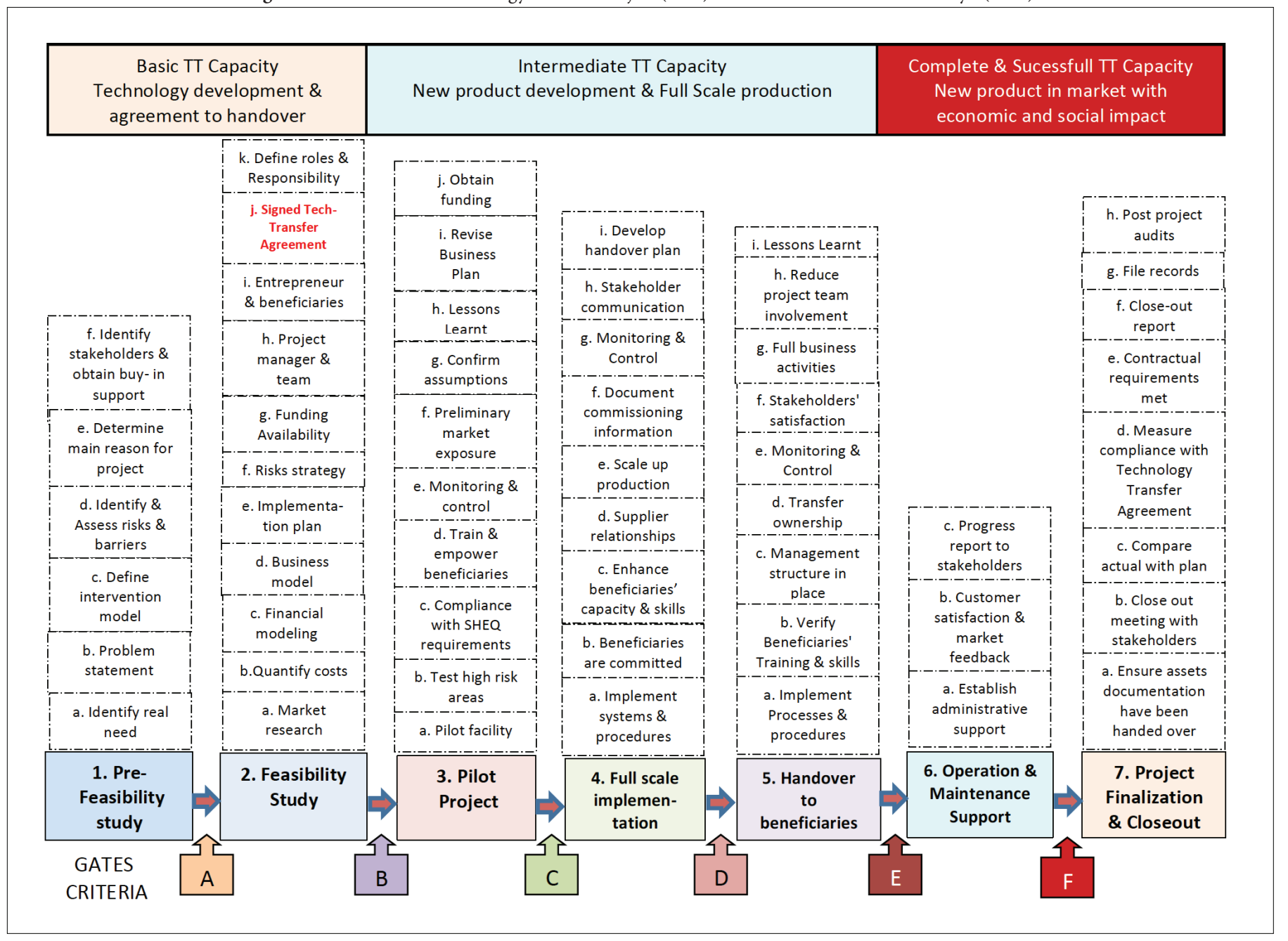


The objective of the post-transfer third stage is adoption, adaptation and innovation. At this stage the maximum initiative is from the transferee end. They should study and act on technology absorption, fine tuning of the technology, see that diffusion takes place across the organization, technology up-gradation and create spirit of innovation; whereas the transferor will create a support system to augment these plans and activities. On a global scale, it involves the successful diffusion and adaptation of innovations from their initial context to another region or country to achieve economic, social, political, or environmental goals.

Interestingly, all the framework elements of the different institutional and academic visions mentioned above, match to some extent with the gates that allow the passage between the different phases of a technology transfer project, proposed by Beukman \& Steyn (2011). As can be seen in Figure 1. Gate A clears the pass from stage 1 Prefeasibility to stage 2 . The Feasibility study requires addressing the real need, identifying the stakeholders and to have at least promised funding since these stages are studies that do not require large sums of money. Beyond that, feasibility needs a good project team to be confirmed, at this point, gate B needs to operate to pass from Stage 2 to Stage 3 Pilot Project. This action requires stakeholders support and commitment and to have funding secured and to develop a plan to mitigate risks. Complete technology information, which is point 2 of UNDESA's framework, permits the transition from stage 3, Pilot plant to stage 4, Full scale implementation. Operation of gate $\mathrm{C}$ requires stressing the stakeholders support and commitment and to have funding secured that, of course, corresponds to point 3 of UNDESA's framework, enabling environment.

Gate D opens the door from Stage 4 Full Scale implementation to Stage 5 Handover to beneficiaries, this step corresponds to point 5 of the UNDESA framework which are mechanisms to facilitate institutional and financial support to technology transfer because the criteria is to have the business fully operating at full scale production. Naturally, technology equipment is operating and providing financial sustainability. At this point beneficiaries must be satisfied.

Probably, in TTP performed in developed countries, to go from the first to the fifth stage could be enough, and they could skip stages 6 $\&$ 7. Of course, the complete model indicates that these stages are required to ensure total success. However, in the TTP performed in developing countries Stage 6 Operation \& Maintenance Support and Stage 7 project finalization and closeout are particularly important. The reason is that the organization that receives the technology requires backup to establish administrative support and reports to stakeholders, giving enough time to measure compliance of the whole operation with the technology transfer agreement terms.

The above conceptual framework considers the execution of projects when funding is a variable not satisfied initially, that is, investors must be sure of the earnings and the financial benefits that will be received. Stakeholders make project evaluations between stages including technological, technical and financing aspects.
A TTP variation occurs when technology transfer is coming from foreign direct investment (FDI) to host regions. This approach integrates firm and regional level analyses using a systemic perspective. In his work, Padilla-Pérez (2008) shows that technology transfer derived from FDI impacts diverse actors of the host region such as local firms, universities, research centers, industry associations, but also that its occurrence is neither automatic nor homogenous across regions.

\section{Methodology proposed}

If we take as initial premise that a technology transfer project (TTP) is a complex inter-organizational process with a huge number of endogenous and exogenous variables, then, its evaluation becomes a problem of meaningful information management. To carry out the objective of this work, we propose a new methodology called Overview Case Analysis (OCA). It consists of four parts or sections: (a) a Case Data Sheet must be built in the first place. It is a document where the analyst must record general information and the main project characteristics, as available. It should include the name of the organizations involved, project timing, results, and a brief free format description, to capture project details that will permit the later discussion and analysis of the case; (b) using information from the case data sheet, a technology transfer project flow graphic must be implemented; (c) using data elements of the data sheet and the graphical information, the analyst should search for the most valuable results of the project in terms of economic and/or social impacts; (d) finally using all the previous information and results, and the coarse scale of the technology transfer capacity, presented in the previous section, the analyst can qualify the success of the technology transfer project.

\subsection{Defining a coarse Scale for measuring an organization's technology transfer capacity}

Based on the TTP conceptual framework descriptions stated in the previous section, it is clear that technology transfer from one organization to another that looks for benefits from the knowledge that it will receive, in the form of new products, systems, and integrated technology in the form of manufacturing or industrial processes, is not just an action that happens only with the signature of a technology transfer agreement at some point in time. It requires a long range project with many actions and evaluation criteria to evaluate if the project continues or not.

Considering Beukman and Steyn's proposal to perform any technology transfer project by organizations of developing countries, we propose the use of the following coarse scale to measure the capacities an organization has to perform TTP's.

Grouping the stages and the activities presented in Figure 1, we define that a Technology Transfer Team $\left(\mathrm{T}^{3}\right)$ has Basic TT Capacity when it is capable of realizing the actions included for Stage 1 Prefeasibility Study and 2 Feasibility Study, ending with the signing of a Technology Transfer agreement.

When the $\mathrm{T}^{3}$ in addition to performing stages one and two, is capable of performing stage 3 Pilot Project, stage 4 Full scale implementation, 
and stage 5 Handover to beneficiaries, the project team has Intermediate TT Capacity because it is able to perform new product development and Full Scale production.

Finally, when $\mathrm{T}^{3}$ in addition to performing stages 1 to 5 , is capable of performing stages $6 \& 7$, we have a project team with Complete \& Successful TT Capacity, which is remarkable and exceptional because it is capable of launching and putting new product on the market with economic and social impacts.

\section{Analysis of cases proposed}

In this section we briefly present four cases of technology transfer projects performed by project teams formed by different academic groups of a Mexican public university and their counterparts, other Mexican organizations. For each case, following the Overview Data Sheet we present the corresponding project flow graphic. Finally, the discussion section is presented for all the cases.

Figure 2 (a) Case 1. Scorpion Antivenom Technology; (b) Case 2. Zinc-Aluminum-Cooper (ZINALCO) alloy; (c) Case

(3) Facial-Skull Implant Prostheses manufacturing process; (d) Case (4) Laboratories for Science teaching in elementary and high schools ${ }^{1}$

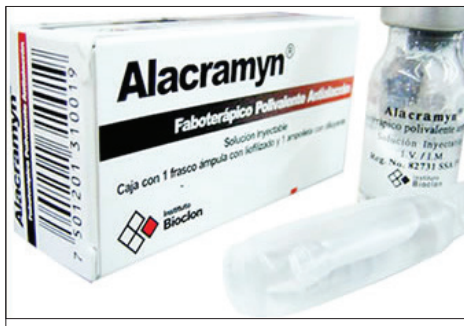

a)

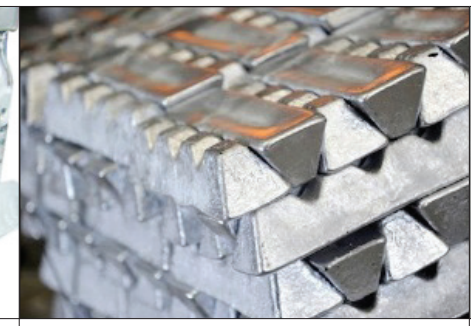

b)

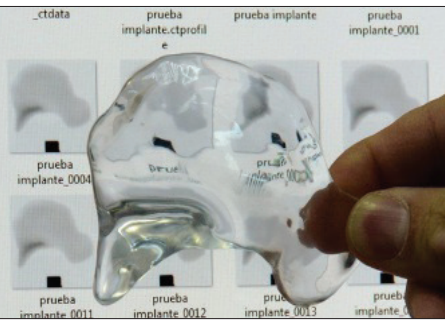

c)

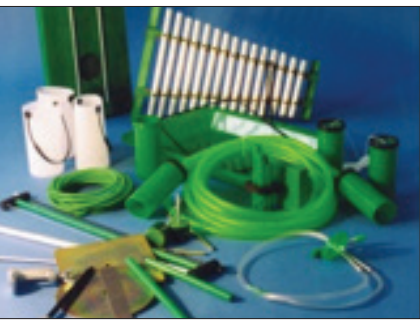

d)

4.1.1 Case 1 Technology Transfer Project: Scorpion antivenom technology

Below is the data sheet of Case 1

Technology Transferor: Instituto de Biotecnología (IBt), Universidad Nacional Autónoma de México (UNAM)

Technology Receiver: Laboratorio Silanes S. A. de C. V. (private company in the Pharmaceutical field, with main offices located in Mexico City)

Heads of Technology Transfer Team (T3): from the IBt Lourival Possani PhD, and Alejandro Alagón Cano PhD; on the side of the firm: Lic. Antonio López de Silanesઐ, legal representative and Araceli Olguín, Quality Affairs

Project time scope: (a) technology development took from 1970 to 2000 and continues. The UNAM R\&D group dedicated more than 30 years to scorpion venom study obtaining national and international field experience. (Herrera 1997; Romero, 2007), (b) intellectual property has taken more than 25 years from 1990 to 2015 and still continues up to now.

Intellectual property: UNAM's scientist obtained the titles for the following patents as a result of their research: US2005065331 (A1)-200303-24 Recombinant immunogens for the generation of genus Centruroides antivenoms, MMX PA04008435A (A) Inmunógeno y antiveneno contra el veneno de la araña violinista. BR PI0514809 (A) inmúnogeno y antiveneno contra veneno o veneno de araña marrom. CL 22232006 (A) Proteína aislada y recombinante del veneno de araña Loxosteles bonetti, etc. US2011177078 (A) Immunogen and antivenom against violinist spider venom.

Technology Characteristics: The scorpion poison antivenom basic technology was first developed by the Biotechnology Institute (BIT: Instituto de Biotecnología) from The Autonomous National University of Mexico (UNAM, Universidad Nacional Autónoma de México); transferred to the pharmaceutical firm: Silanes* Labs (Laboratorios Silanes) for its commercialization, this Enterprise developed the poison antidote industrial fabrication process through Bioclon, its research and development Institute. Silanes first launched the antivenom product into the Mexican local market and through the years it developed new markets in some North African countries and in the USA. (Vega-González, 2012)

Project Milestones: UNAM-Silanes Collaboration and TT Agreement signed probably in the 1980-1990 decade (precise data N/A), creation of Bioclon R\&D Institute by Silanes to develop new antivenom products, produce and commercialize them. Alacramyn (antivenom commercial name) launch to sale in 2000, Anascorp (USA antivenom commercial name) FDA Approval in 2011. Investment of 40MUSD in 2011 for two new production facilities in the State of Mexico. (Silanes Noticias, 2011)

Impacts: declared sales for \$100 million USD in 2011, estimated \$500 MUSD for 2017, estimated 500,000 life's saved every year, with the global use of the family of antivenom products.

(1) Photographs: Case 1 and 2 public domain (google images); Cases 3 and 4 CCADET-UNAM's property. 
The TTP project flow graphic for case 1 is presented in Figure 3

Figure 3 Case 1 Antivenin Technology Project lifecycle graphic. (Vega-González, 2012)

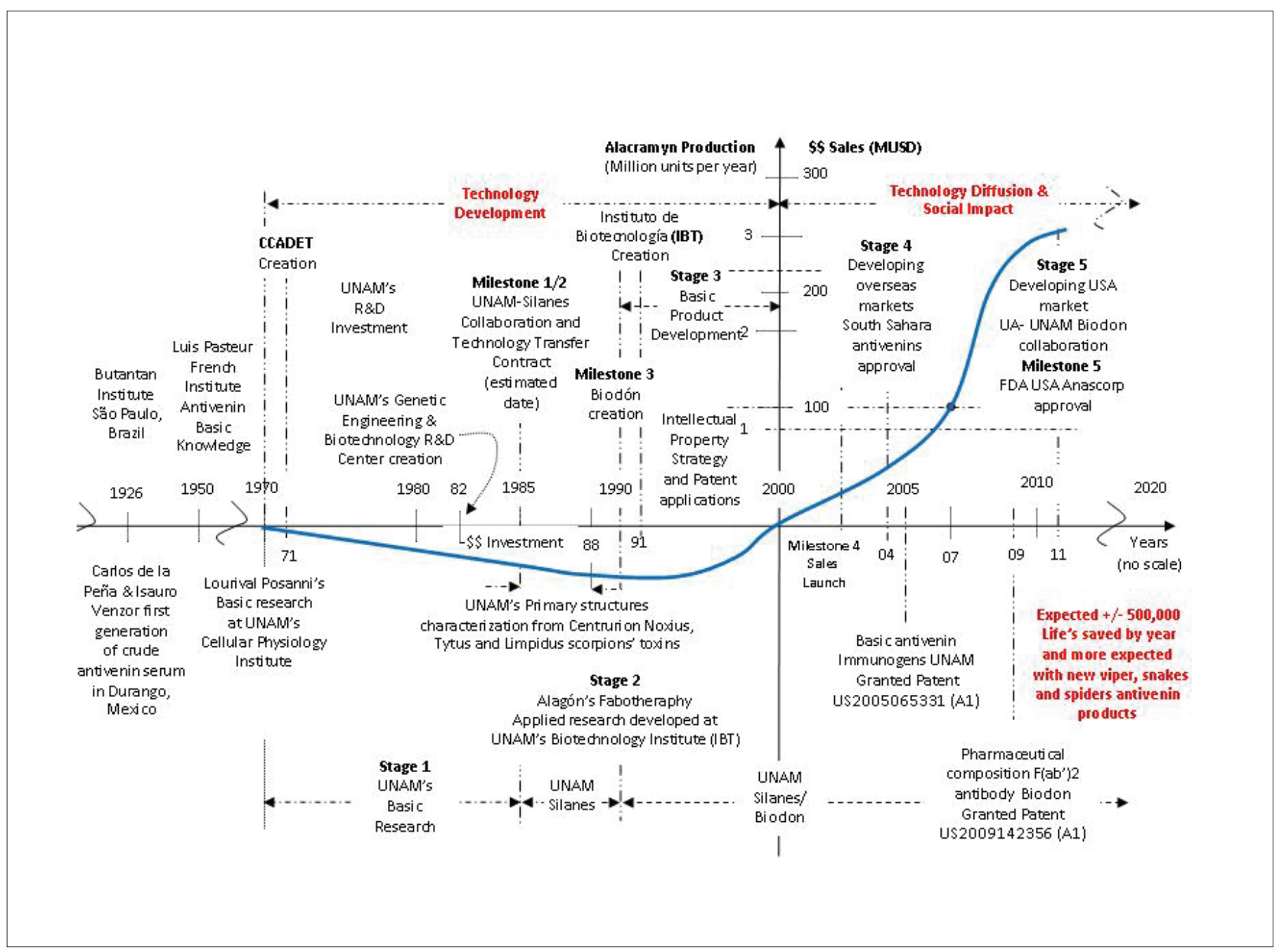

4.1.2 Case 2 Technology Transfer Project: Zinc-Aluminum-Cooper (ZINALCO) alloy

Below is the data sheet of Case 2

Technology Transferor: Instituto de Investigación en Materiales (IIM), Scientific Research Subsystem, Universidad Nacional Autónoma de México (UNAM)

Technology Receiver: Fundición FALMEX S. A. de C. V; private company in the Foundry field, with main offices located in Mexico City. Falmex received the Zinalco technology at Laboratory level and performed pilot industrial testing. Then, since they did not have the industrial installation to produce Zinalco, they signed a contract with ALCOMEX for the industrial production of the alloy during the 80s. Later, in 1992 a new company began participating in the project, the giant Industrias Unidas SA de CV (IUSA), a private company in many fields of industry, including the production of copper alloys for the electrical cable and the water tubes industries. In February 1993 the licensing rights of Zinalco Technology exploitation were transferred from Falmex to Zinalco Industrial with UNAM's approval. Later, in july 1993 Zinalco Industrial S.A. de C.V. company was created with $45 \%$ stock participation of IUSA and $28 \%$ Falmex.

Heads of Technology Transfer Team (T3): from the UNAM's IIM: Gabriel Torres Villaseñor, PhD, Jesús Negrete Sánchez, PhD, Alfredo Valdez Hernández PhD; on the side of the firm: Lic. Ramón Galván Cavazosґ, legal representative FALMEX S.A. de C.V.; and Luis Miguel Galván Cavazos; Ing. Alejandro Peralta Soto, legal representative and General Director of the Controls Group of Industrias Unidas S.A. de C.V. (IUSA). Jaime Martuchelli PhD Center for Technology Innovation UNAM. 
Project scope: the UNAM R\&D group has dedicated more than 50 years to the study of aluminum alloys. Since 1973, with funds from the American States Organization (OEA), IIM has developped research lines on copper and zinc, additionally the IIM has a research line in metallic aluminum based materials.

Intellectual property: Intense intellectual property efforts were made particularly in the 80's and 90's. UNAM's scientist obtained the titles for the following patents as a result of their research: 164,705-1992 Improvement on the anodized process for Zn-Al-Cu alloys; 164,818-1992 Improvements to the method for passivation of $\mathrm{Zn}$-Al-Cu alloys; 172354-1993 process for semi-continuous casting of $\mathrm{Zn}$-AL-Cu alloys to obtain circular bars with fine dendritic structure; 294,849-1983 Zinalco Trademark. Following patents were obtained as co property between UNAM and Falmex: Mexican patent No. 161,143 "Process for obtaining profiles from zinc, aluminum and copper alloys"; Mexican patent application No. 200,935, Improvements to the method to passivize zinc-aluminum-copper alloys, Patent in Peru No. 4379; Mexican patent No. 70,912 "Improvements to the basic anodization process of zinc-aluminum-copper alloys"; Mexican patent application No. 17,400 "Process and equipment of semi-continuous casting of Zinalco to obtain circular dendritic bars"; Falmex Mexican Patent application No. 25,153 "Improvements to the process for obtaining profiles from zinc, aluminum and copper alloys", same patent request in Europe, USA, Japan, Peru (4380) ; Zn-Al-Cu alloy rolling process; Falmex Mexican patent application Nr. 91-00915 “Zinc alloys and their applications to industrial processes". UNAM registered in 1988 the Mexican ZINALCO trademark Nr. 294,849. Mexican trademark ZINALDIC Nr. 361807.

Technology Characteristics: Zinalco is an alloy from the combination of zinc, aluminum and copper; in 1983 It was possible to specify the precise alloy to obtain a material with weight/mechanical resistance relation similar to the aluminum series 6000 . This achievement permitted that the alloy be processed in foundry, injection, lamination and extrusion. Zinalco can be used to manufacture: extruded profiles, gears, carburetors, pump housings, transmission parts, structures, roofs, valves, filters, regulators, electrical boxes, electrical conduits, and beaks parts, artistic and decorative objects. The goal was the use of Zinalco for the substitution of traditional materials such as brass, bronze, aluminum, zamak, gray iron and steel. Zinalco properties are: fusion temperature 421 to 481 DEGC, Density $5.4 \mathrm{~g} / \mathrm{cc}$, elastic module 110 to 130 Gpa, electric conductivity: 37\%, thermal conductivity 37\%, thermal expansion coefficient 25 micrometers/mmk, color grayish white. The alloy has a mechanical resistance similar to low carbon steel and high corrosion resistance like aluminum. Since the late 90 's till now research has been oriented to the super-plasticity of the material and its biomaterial properties. Zinalco's superplastic deformation goes up to $500 \%$. Zinalco can be used in the metal-mechanical industry and construction, among others. it was expected that the commercial potential of the alloy will grow when it replaced the import of low production metals in Mexico, such as zinc, lead, cadmium, mercury and bismuth. Zinalco alloy has the mechanical strength of structural steel, combined with the corrosion resistance of aluminum and an intermediate density. It does not weigh as little as aluminum, but it weighs $35 \%$ less than steel. It can be used in the manufacture of rods for machining or castings, previously made with brass and bronze; it can also be injected under pressure into a mold and make parts that were previously made of steel, like gears, but cheaper. An important property is that under certain rolling conditions it can behave like a plastic and return to being a steel. That versatility is unique in this material. Between 1979 and 1984 the majority of the alloy was characterized, and by 1991 there was already an acceptable industrial production.

Project Milestones: Two technology transfer contracts between UNAM and Falmex Industrial were signed in 1984 and june 1986 to implement different industrial processes to produce extrusion profiles to build window frames. Expected annual sales were 3126.4 tons, at a sale price of $\$ 5.00 \mathrm{USD} / \mathrm{Kg}$, will produce sales of $\$ 78,175,000.00 \mathrm{USD}$ in five years. The agreed royalty rate was $2.5 \%$ on sales of Zinalco based manufactured products. Falmex-Galvotec created the firm Zinalco Industrial SA de CV in 1993 to develop applications and final products using the alloy with shareholding divided between Falmex and IUSA. From 1993 to 1996 it was carried out the industrial scale up of Zinalco for manufacturing of safety gas valves, coins, and diverse car and bathroom accessories. In 1993 Falmex participated in an extraordinary bid for about 5000 gas safety valves. Their strategy was to produce the alloy material and the Zinalco molds to manufacture the valves body and parts, in order to offer them with immediate delivery. Regrettably, Falmex lost by price, competing with IUSA who was the bid winner offering the manufacturing of bronze valves and an extraordinary price discount since they controlled the production margins in the copper alloy industrial production in México. The valves produced by Falmex for the bid had to be discarded. The company went bankrupt and was forced to sublicense the technology to IUSA with UNAM's acceptance. Falmex went out of the market in 1997 and UNAM received a single royalty payment for less than \$5,000 USD from IUSA. Finally IUSA advised UNAM that they will stop production of Zinalco because in the reverberation ovens they used to melt and produce copper alloys, they needed to reuse waste materials of pure composition. Since Zinalco alloy wasn't pure itself, its composition makes it impossible to reuse the waste material in the process. This particularity increased production costs enormously, they said, motivating the end of Zinalco industrial production. UNAM's technology, its patents and the Falmex patents were frozen and haven't been exploited since then.

Impacts: According to José Antonio Esteva Maraboto former director of the UNAM’s Technology Innovation Center in 1995, the development of Zinalco cost about \$2 MUSD including OEA's funding and different international grants obtained through the years. This quantity also included the payment of researchers and the equipment bought during the development years. UNAM only received royalties for about $\$ 1,000$ USD. Nevertheless, through the years many other benefits occurred with this project, several PhD's, MSc and Engineers were formed and the UNAM's $\mathrm{R} \& \mathrm{D}$ and technology management teams learned a number of management of technology lessons. 
The TTP project flow graphic for case 2 is presented in Figure 4

Figure 4 Case 2 Zinalco's Alloy project lifecycle graphic ("estimated dates)

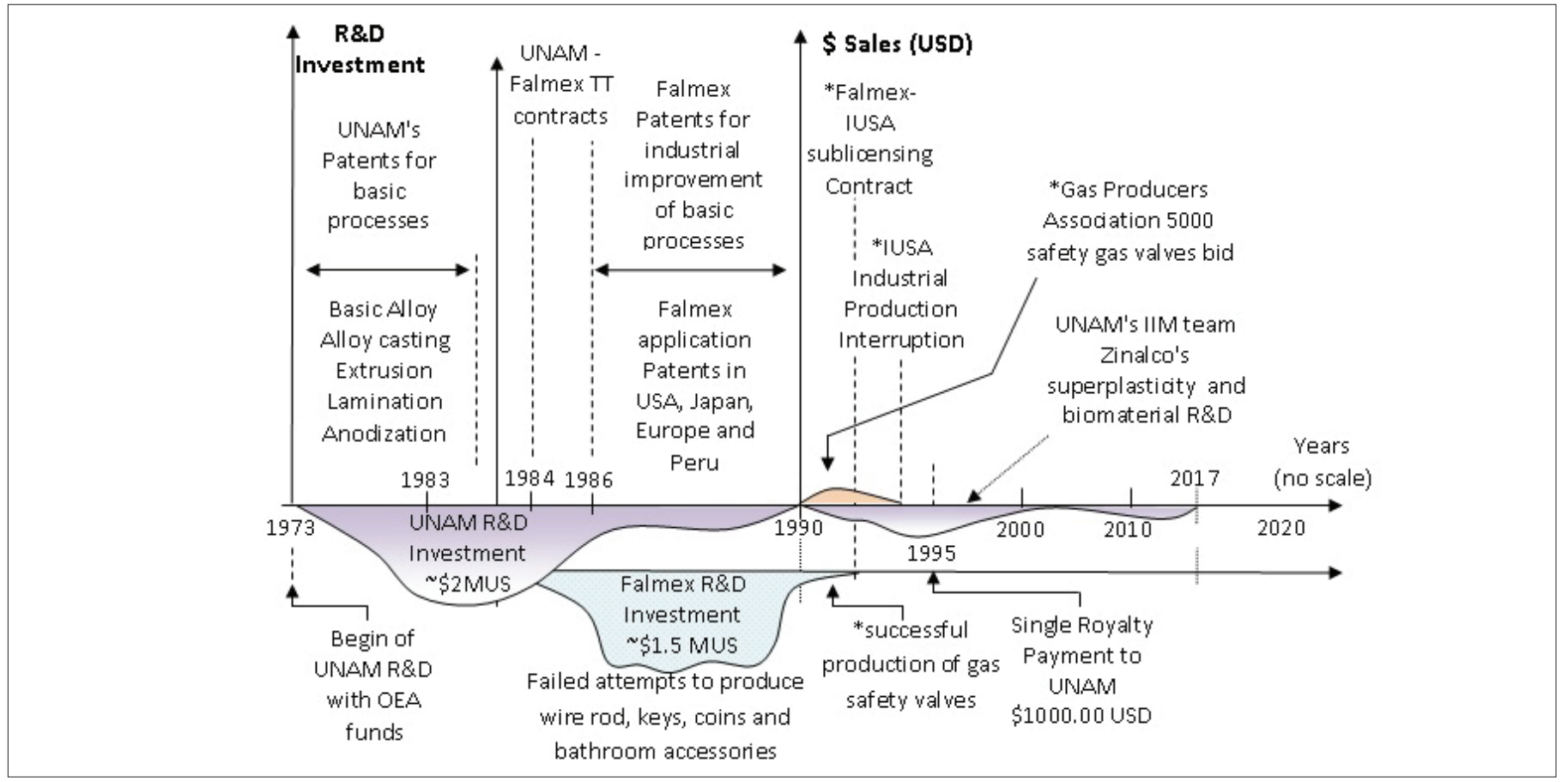

\subsubsection{Case 3 Technology Transfer Project: Zinc-Aluminum-Cooper (ZINALCO) alloy}

Below is the data sheet of Case 3

Technology Transferor: Centro de Ciencias Aplicadas y Desarrollo Tecnológico (CCADET), Universidad Nacional Autónoma de México (UNAM)

Technology Receiver: Partes e Implantes Avanzados S. A. de C. V. (private company in the biomedical supplies field, located in Guadalajara Jalisco, México)

Heads of Technology Transfer Team $\left(\mathrm{T}^{3}\right)$ : from the UNAM's CCADET: Leopoldo Ruiz Huerta, PhD, and Alberto Caballero Ruiz PhD; on the side of the firm: Juan González Luna Marceille, legal representative and project head.

Project description: January, 2011, Dr. José Narro Robles, Rector of UNAM established the program called Interdisciplinary Research Seminar in Biomedicine. The main objectives were to provide a space for researchers from different academic areas to present and reflect on their research projects by stimulating the linking and generation of original ideas that can be applied to the health areas, as well as speeding up the innovation process, encouraging the development of talent and transferring research to society. Derived from this Seminar, the head of the research area of the Hospital General de México and academic members of Applied Sciences and Technology Development Center (CCADET, Spanish acronym) proposed and negotiated the signing of a Specific Collaboration Agreement for the establishment of a Research and Development Unit (UIDT) of the CCADET at the Hospital. This agreement was signed in February 2012. By the end of that year the UIDT was operating and used a space of about $85 \mathrm{~m}^{2}$ at the HGM installations. On the other hand, in 2014 the National Council for Science and Technology (CONACYT, for its Spanish acronym), approved the UNAM's proposal to implement a "National Additive Manufacturing Laboratory, 3D digitalization and Computerized Tomography" (MADIT, for its Spanish acronym). This project was filed with the number 232719 and the original institutions network included the Hospital General de México (HGM), the Yucatan's Autonomous University and the Technological Superior Studies Monterrey Institute (ITESM). In a conference held in 2014 at the HGM, medical members of the maxillo-facial HGM's Department presented the problem they had to produce PMMA implants using molds. The academic coordinators of the MADIT's National Laboratory established collaboration with the HGM's doctors and by the end of that year the implants manufacturing solution using digital technologies emerged. The project protocol required the testing of molds manufactured with new technology in hospital patients. Protocol testing was approved by the medical committee and by the end of 2015 the firm Partes e Implantes Avanzados SA de CV expressed its interest in obtaining the licensing of the manufacturing technology. With HGM's research area authorization, a five years Technology Transfer and Licensing Agreement was signed in February 2017 between UNAM and the firm. 
Intellectual property: UNAM obtained author rights register in 2015 for the technical report "Optimization of the manufacturing process for facial-skull implants using Polimethyl Methacrylate (PMMA) with additive manufacturing techniques", besides, the UNAM R\&D team put together the information elements to produce an Industrial Secret special document for the manufacturing process to obtain high quality products (implants)

Technology Characteristics: the technology for skull-facial implants was developed by the Additive Manufacturing, 3D digitalization and Computerized Tomography (MADIT) CCADET's National Laboratory in collaboration with the team of Maxillary-Facial Surgery medical team of the Mexico's General Hospital where the CCADET by agreement has a Research and Technology Development Unit (UIDT, Spanish acronym). MADIT's National Laboratory promotes research and development in the field of additive manufacturing (design, materials, properties, processes, among others), and 3D scanning and nondestructive testing in different fields of science The idea was to use this new technology to substitute the old molding process to prepare a facial-Skull prostheses. The old fashion facial-Skull PMM prostheses prepared using traditional methods and used by the General Hospital Surgeons required an average of 15 to 20 days to prepare because manufacturing was a completely manual craft process. The surgeon's technical team usually took a sample of the implant needed by using a soft paste mold and adjusting it gently. They produced the male and female mold, in PMMA and cured it. Regrettably the craft implants sometimes required adjustment during the surgery, taking a longer time and making it more traumatic. The benefits of using the implants produced using additive manufacturing and computerized techniques are that it only takes from three to four days to be ready and tested to be used in surgery. Up today there have been no rejections in a number of surgeries and prostheses implanted since 2015. Implants fit and adjust 100\% in the patients.

Project Milestones: (a) January 2011 UNAM’s Rector José Narro established the Interdisciplinary Research Seminar in Biomedicine; (b) February 2012 signing of the collaboration agreement between UNAM and the Hospital General de México for the creation of a Research and Development Unit (UIDT) of the CCADET at the Hospital; (c) technology development in 2013; (d) first skull prostheses used in a surgery at the end of 2013, (e) intellectual property copyrights and trademark obtained in 2015 and industrial secret for the manufacturing process in 2017; (f) February 2017 a five year Technology Transfer and Licensing Agreement was signed between UNAM and the firm Partes e Implantes Avanzados S.A. de C.V.

Impacts: the private firm that received technology transference has made a market profile study finding that only in Mexico City's General Hospital there is an average of 15 to 20 patients per month that require some implant surgery, expanding this to the regional hospitals of Mexico City and the major cities of the Mexican Republic, it is expected that demand will increase up to one hundred and fifty (150) implants per month, or about 1800 implants per year. UNAM reserved its right to modulate the final public price of implants in order they be affordable for the average patient. They will also have a clause in the technology transfer agreement to assign two implants per year with no cost for the poorest people who require implants but do not have enough economic resources to afford them, according to a social worker study. With $\$ 500.00$ USD implant average price, expected sales are $\$ 1,250,000.00$ USD per year and royalties for about $\$ 40,000$ USD. The expectation is that PMMA digital implants could save about 1000 lives a year from 2020.

The TTP project flow graphic for case 3 is presented in Figure 5

Figure 5 Case 3 Facial-Skull Implants project lifecycle graphic ( ${ }^{*}$ estimated dates)

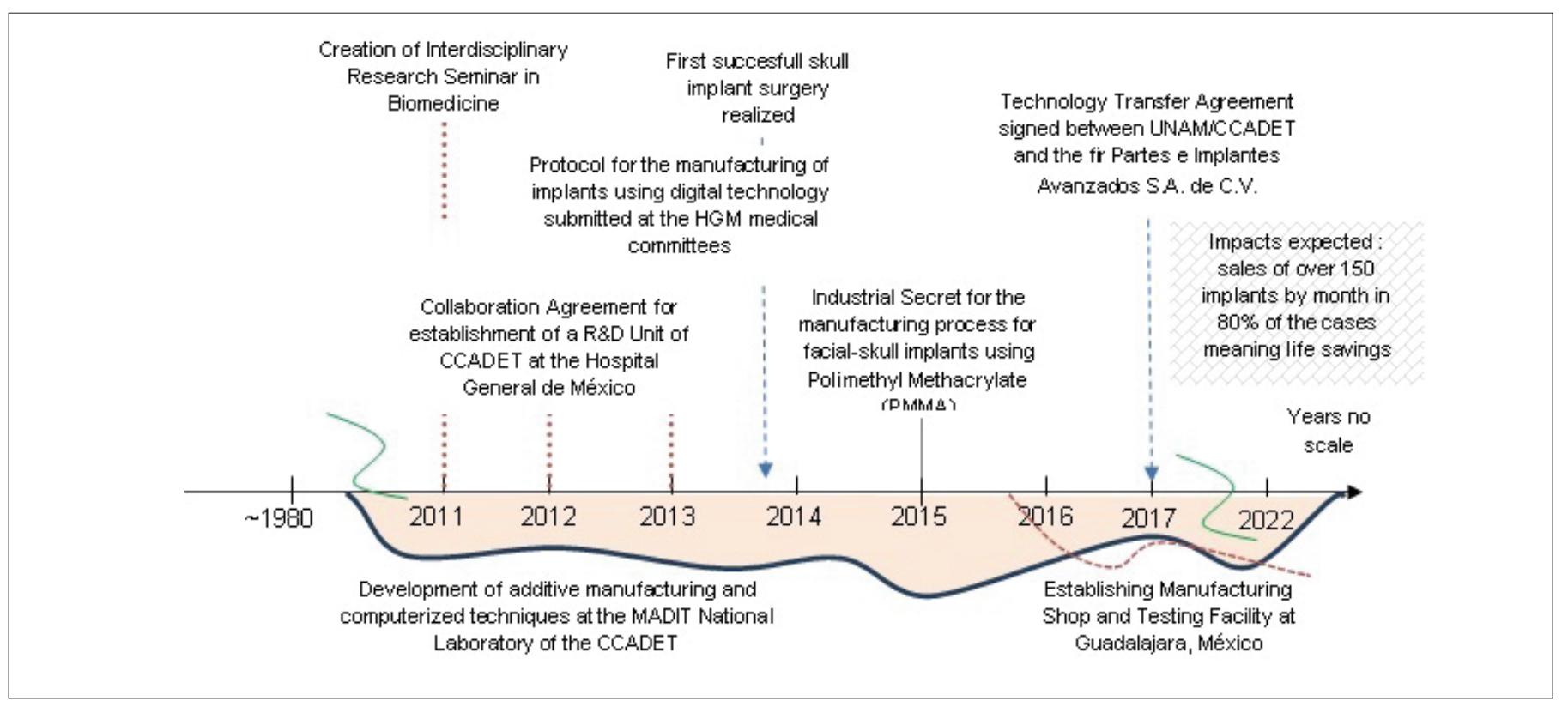




\subsubsection{Case 4 Technology Transfer Project: Laboratories for Science Teaching in elementary and Secondary Schools}

Below is the data sheet of Case 4

Technology Transferor: Centro de Ciencias Aplicadas y Desarrollo Tecnológico (CCADET), Universidad Nacional Autónoma de México (UNAM) which is a public university.

Technology Receiver: Fernandez Editores SA de CV (private firm in the editorial field)

Heads of Technology Transfer Team $\left(\mathrm{T}^{3}\right)$ : from the UNAM's CCADET: Leticia Gallegos Cázares, PhD, and Fernando Flores Camacho, PhD; on the side of the firm: Jesús Garduño Lamadrid, legal Representative. Fernandez Editores S.A. de C.V. was founded by Luis Fernandez in 1943. It began industrial operations in 1986 with Tomas Garza Villarreal, operating with licenses from Walt Disney and Warner Bros for education. The company developed a distribution network in all regions of México, and has regional warehouses. It is leader in editions for elementary and secondary schools in the country. Till now, they dominate the market of texts and reference books for the Ministry of Education of Mexico. In 1999 UNAM signed a five year license agreement with Fernandez, covering the Labs of: Physics, natural sciences, sound, fluids, astronomy, heat, electricity and magnetism and light and optics. In 2005 Fernandez \& the UNAM participated in several bids for the Secretaría de Educación Pública (Federal Ministry of Education in Mexico). Later, in September 2006 UNAM signed six different licensing agreements with Alberto Levet Contreras, Fernandez’s General Director, and Tomas García Cerezo, Editorial Director, covering the Laboratories of Light and optics, Natural Sciences, Electricity and Magnetism, Mechanics, Sound and Modular Mechanics for elementary and high schools.

Project time scope: (a) the CCADET's Cognition \& Science Didactics academic group have developed technology for teaching science since 1975. This UNAM group has had an intense link with diverse organizations from the public and private sectors. They have dedicated more than 30 years to the development of didactic material, learning units, for teaching science even for indigenous schools (b) an intellectual property strategy has been advocated for the protection of books and laboratory manuals via author rights for more than 25 years since the late 1980 's up to 2015 and still continues up to now.

Intellectual property: Copyrights: “Laboratorio de Ciencias Naturales, Manual de Prácticas para Educación Básica” (03-2004-05271135580001); “Manual de Prácticas de Mecánica” (03-2004-052711433100-01); “Ciencias Naturales, EDUCIENCI” (03-2004-112312023900-01); Laboratorio de Electricidad y Magnetismo, Manual de Prácticas para Educación Básica” (03-2004-112210554000-01); "Educación en ciencias para Preescolar Luz y Óptica EDUCIENCI" (03-2006-092513260800-01); "Hojas de Registro 1er. Grado Luz y Óptica, observaciones de experimentos en Ciencias" (03-2006-092513245300-01); Carro de servicio para Laboratorios de Ciencias (03-2006-092513291900-01); "Hojas de Registro 3er. Grado Luz y Óptica, observaciones de experimentos en Ciencias” (03-2006-091413274700-01); Manual de Actividades de Óptica para estudiantes de secundaria y bachillerato" (03-2010-042213032200-01); "Electricidad y Magnetismo, Guía de uso de la Bobina de Inducción para demostraciones" (03-2010-051309562500-01); "Electrostática, Actividades con el generador electrostático Van de Gras y el graficador de líneas equipotenciales" (03-2010-051309550200-01); “Marco de Fuerzas, Manual de actividades experimentales” (03-2010-051309554700-01); "Placas de Magdeburgo y cámaras de vacío, Manual de actividades experimentales” (03-2010-051309542800-01); "1-6 Biología Ciencias Naturales Primaria Seres vivos y cuerpo humano. Laboratorio Integrado de Actividades para Primaria” (03-2010-062411352000-01); “1-3 Física Ciencias Naturales Primaria Materia, energía y cambio. Laboratorio Integrado de Actividades para Primaria” (03-2010-061712172800-01); 4-6 Física Ciencias Naturales Primaria Materia, energía y cambio. Laboratorio Integrado de Actividades para Primaria" (03-2010-06171216040001); Hojas de registro combinación de colores luz y óptica, observaciones de experimentos en ciencias (03-2012-052312365300-14); Hojas de registro formación de sombras luz y óptica, observaciones de experimentos en ciencias (03-2012-052312423900-14); Hojas de registro imágenes en espejos y lentes luz y óptica, observaciones de experimentos en ciencias (03-2012-052312423900-14); Hojas de registro imágenes en espejos y lentes luz y óptica (03-2012-052312341300-14); Trademarks “EDUCIENCI” (379141- 1990); “EDUCIENCI” Y DISEÑO (507355-1995).

Project Characteristics: The CCADET Cognition and Science Didactics academic group for the last forty years, has contributed to the national education System with different pedagogic proposals sometimes financed by the Public Education Secretary (SEP, by its Spanish acronym), promoting science education in kinder garden, elementary, secondary and high schools

Project Milestones: UNAM and Fernandez Editores SA de CV signed a first Technology transfer and licensing agreement in 1999, including 8\% Royalties, for the following Physics Laboratories: Sound, Fluids, Astronomy, Mechanics, Heat, Electricity and Magnetism, Light and Optics, and the Natural Science Lab. In 2006 five new technology transfer and licensing agreements were signed, for each of the following Labs: Light and optics, Modular Mechanics, Mechanics, Sound, Natural Sciences and Electricity and Magnetism.

Impacts: Fernandez Editores production and distribution efforts in conjunction with the support of the CCADET's academic team permitted the UNAM Science Laboratories to be used by Public Education Secretary Schools for about 10 years from 2000 to 2011. More than 5000 Labs of each type were sold. UNAM received royalties for an estimated of $\$ 7$ Million Pesos, about $\$ 400,000$ USD. Furthermore, with this project the TT team contributed to improving the science education to thousands of students probably fostering their vocation toward sciences. Between 20,000 and 25,000 elementary, high school and Kindergarten students were benefited. 
The TTP project flow graphic for case 4 is presented in Figure 6

Figure 6 Case 4 Laboratories for teaching science i elementary and high schools

\begin{tabular}{|c|}
\hline 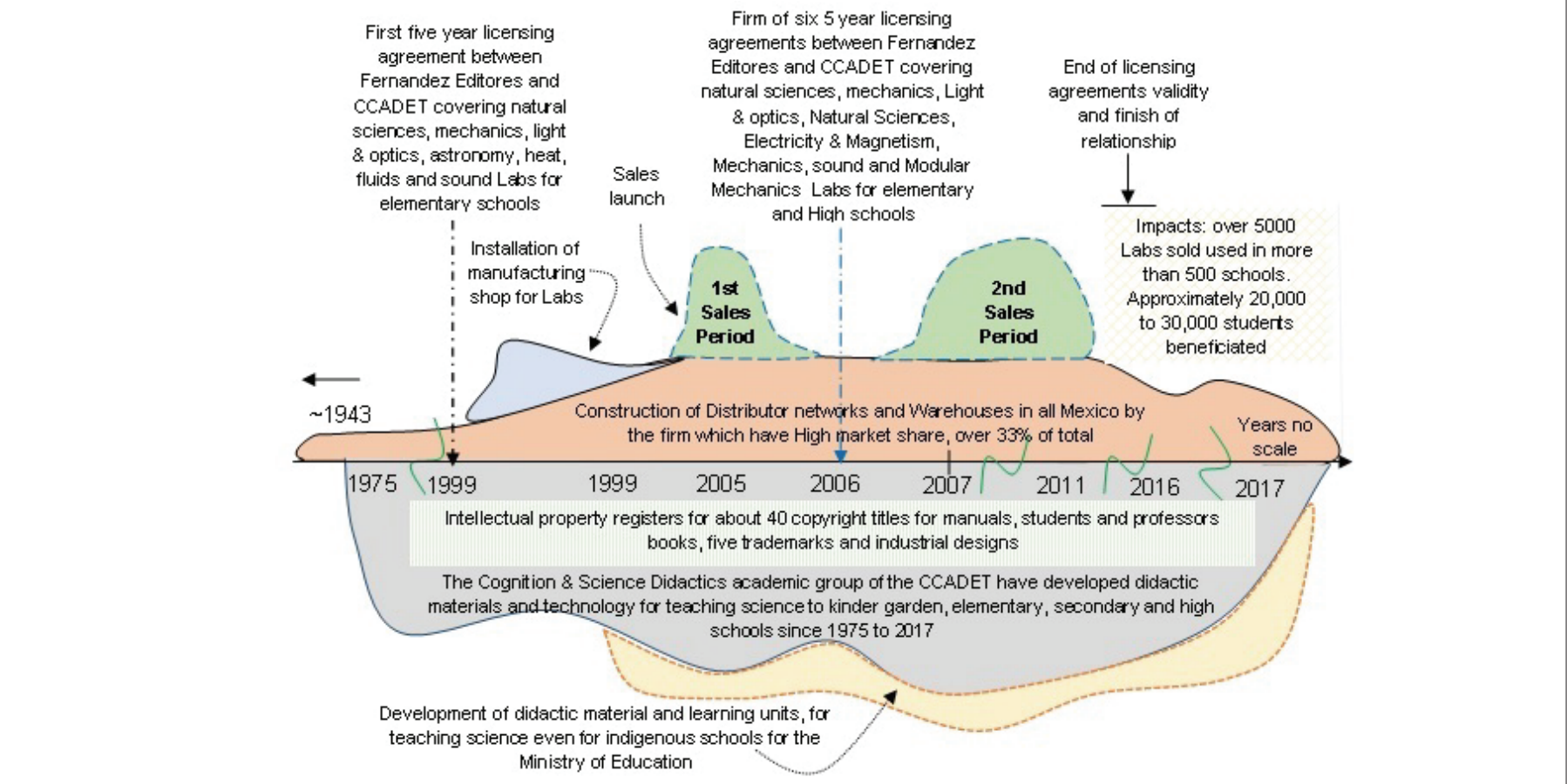 \\
\hline
\end{tabular}

\section{Discussion and results}

During its lifespan, each project followed the activities of the different stages of Beukman \&Stein's (2012) model of Figure 1, including impacts, etc.

\section{Case 1. Scorpion antivenom technology}

From the Case Data Sheet we have the following relevant aspects

Organizations involved in the Technology Transfer had very good reputation; UNAM's Biotechnology Institute and Laboratorio Silanes, Pharmaceutical Company with recognition and presence in the market.

Intellectual Capital: Individuals of the Technology Transfer Team $\left(\mathrm{T}^{3}\right)$ had a high level in scientific and business management affairs.

Time scope: project took over 30 years and intellectual property for more than 25 years. Mature project with results well protected with more than five (5) specific patents.

Technology Level: mature, launched to the market in 1980 tested in real environmental conditions with specific target of scorpion venom, with FDA approval under the qualification of orphan product, practically level 7 of NASA Technology Readiness Level Scale (TRIZ). (Olechowski et al., 2015)

Project Milestones: Silanes created the R\&D Center Bioclón with the specific objective of developing commercial antivenom products
Alacramyn (antivenom commercial name) launch to sale in 2000, Anascorp (USA antivenin commercial name) FDA Approval in 2011. Impacts: sales of over $\$ 100$ million USD in 2011, estimated $\$ 500$ MUSD for 2017. Estimated over 100,000 lives saved by the global use of the antivenom products in its lifespan

\section{Case 2. Zinalco Alloy}

From the Case Data Sheet we note relevant aspects: High level Technology Transfer Team $\left(\mathrm{T}^{3}\right)$ with both scientific and business management capabilities. Strong technology knowledge: UNAM R\&D group has dedicated more than 50 years to the study of aluminum alloys and since 1973, with funds from the American States Organization (OEA), IIM has develop research lines on copper and zinc, additionally the IIM has a research line in metallic aluminum based materials. Project Strength in Intellectual Property; more than ten process patents in Mexico, EUA and Peru.

Extraordinary Technology Characteristics: Zinalco is an alloy from the combination of zinc, aluminum and copper; in 1983 It was possible to specify the precise alloy to obtain a material with weight/mechanical resistance relation similar to the aluminum series 6000 . It also has superplastic characteristics and is biocompatible.

In the late 1990's the company Zinalco Industrial was created to produce and sell Zinalco. Directives did not have a clear view of the competitors and the company was broken in two years. 
Research and development cost over 2 million USD but technology could not reach the market.

\section{Case 3. Facial-Skull Implants Prostheses manufacturing process}

This is a young promising project, the Technology Transfer Team $\left(\mathrm{T}^{3}\right)$ has high R\&D and firm qualifications.

Project derived from the Research and Development Unit (UIDT) of the CCADET at the Hospital General de México. Technology developed by members of the National Additive Manufacturing Laboratory, 3D digitalization and Computerized Tomography" (MADIT, for its Spanish acronym) to help fulfill the continuous requirement of skull prostheses at the Hospital.

Technology was licensed by the UNAM signing a Technology Transfer and Licensing Agreement with the firm Partes e Implantes Avanzados SA de CV with five years validity. The intellectual property used were author rights and the industrial secret for "Optimization of the manufacturing process for facial-skull implants using Polimethyl Methacrylate (PMMA) with additive manufacturing techniques". The characteristics of the technology transferred overpasses the handmade prostheses manufacturing process improving time, quality and with $0 \%$ rejections. The sales potential of the technology is very good but the main expectation is that PMMA digital implants could save about 1000 lives a year after 2020 .

\section{Case 4. Laboratories for Science Teaching in elementary and Secon- dary Schools}

High profile Technology Transfer Team, Fernandez Editores S.A. de C.V strength was market control through their book distribution network. UNAM's Intellectual property mainly based on about two dozen manual copyrights. More than 5000 Science laboratories were sold and more than 20,000 students of different levels were benefited. Very good technology transfer contracts, well negotiated. Table 1 shows the qualifications summary of the cases presented.

Table I. Summary of qualification highlights of presented cases

\begin{tabular}{l|l|l|l|l}
\hline Case & $\begin{array}{l}\text { Technology Transfer } \\
\text { Team (T3) }\end{array}$ & $\begin{array}{l}\text { Technology maturity/ } \\
\text { Level }\end{array}$ & Impacts \& market & $\begin{array}{l}\text { Technology Transfer } \\
\text { Capacity coarse scale }\end{array}$ \\
\hline $\begin{array}{l}\text { 1 Scorpions Antivenin } \\
\text { 2 Zinalco Alloy }\end{array}$ & High Level & TRL 7-8/High Tech & $\begin{array}{l}\text { Social over 100,000 Lives saved, Sales } \\
\text { over 200 USD by year }\end{array}$ & $\begin{array}{l}\text { Complete \& Successful with great } \\
\text { economic and social impact }\end{array}$ \\
\hline $\begin{array}{l}3 \text { Facial-Skull Implants digi- } \\
\text { tal Manufacturing Process }\end{array}$ & High Level & TRL 5-6 & No market share & Basic-Intermediate. Not successful \\
\hline $\begin{array}{l}4 \text { Laboratories for teaching } \\
\text { of Science }\end{array}$ & High Level & TRL 7 & $\begin{array}{l}\text { Expected high impact over 150 } \\
\text { implants sold by year. Market with no } \\
\text { national competitors }\end{array}$ & $\begin{array}{l}\text { Intermediate } \\
\text { Expectation of great success }\end{array}$ \\
\hline
\end{tabular}

\section{Conclusion}

The basic information required to use the Beukmans (2011) model of technology transfer project activities, was obtained from the cases presented using the Overview Case Analysis methodology presented in this article. This methodology only can be applied case by case, therefore it doesn't allow us to obtain statistically proven conclusions, but it is a good tool that makes evident the relevant project characteristics of the phenomenon.

In the cases presented we found that one of the conditions for a technology transfer project to be successful is the technology maturity level. It can be seen that the TRL of the technology of successful Cases 1 and 4 were qualified from seven to eight. Naturally, good university technology attracts the interest of companies.
In second place, the success of a TTP depends on the relation of the transferor and the transferee. In that regard, from the results and the previous discussion, we found that in order for a technology transfer project to reach the grade of Successful \& Complete the project must be handled by a well-integrated multidisciplinary team between the organizations involved, technology transferor and technology receiver, which must have mutual commitment. For a steady project advance, it is advisable that at least the heads of the Technology Transfer Team $\left(T^{3}\right)$ must work together in the project through stages 1 to 7

Now, extending the concepts of Eliezer Geisler (2002), in the sense that we cannot evaluate technology unless and until we put it in the context of social and economic phenomena, or until and unless we put a human dimension upon it, then, we can think that a technology transfer project cannot be successful if there are no measurable 
economic and social impacts arising from them. In that regard Case 1 Scorpion antivenom technology obtains the first place followed by Case 4 Laboratories for teaching of science. In that vein, there is a great expectation that Case 3 Facial-Skull Implants will have future with increasing economic and social impacts.

We have to mention that we found that the intellectual property strategy of the part that owns the technology can be varied and does not always rely on patents. The investigation indicated the technology transfer on Cases $1 \&$ and 2 were supported on well-structured patent families, nevertheless Case 2 failed. On the contrary, Case 3 was supported as an industrial secret and is very promising, while Case 4 was based only on copyrights and it qualified as a complete and successful project with medium social and economic impacts.

Another important conclusion is that the success of a technology transfer project does not depend on the amount of investments of capital and human resources, as can be seen in Case 2 Zinalco alloys; this project could not reach the market, and therefore there were no social nor economic impacts, even with the important amount of knowledge developed in it. This project also teaches us that the mere possession of the technology is not a guarantee that it will be utilized. Zinalco's technology was transferred to the firm Industrias Unidas (IUSA) which is one of the most important industrial conglomerates in Mexico, but they did not push the technology to reach the country market.

Finally analyzing the results of research surveys, Shrestha, (1995) found that organizational culture barriers, lack of time, capacities, attitudes of individuals, and lack of clear policy are the major barriers to technology transfer in joint venture construction companies. Accordingly, Kundu et al., (2015) expressed that doubtlessly, the success of technology transfer depends on the right selection of technology and partner as well as on the right method of transfer.

With the results of the cases presented in this article we have been able to prove that the success of the TTP goes beyond the selection of the partner and the method of transfer, it also depends on the establishment of an efficient technology transfer team $\left(T^{3}\right)$, the technology maturity and the technology assimilation and diffusion that produces important economic and social impacts.

\section{Acknowledgement}

We thank Neil Bruce Davidson PhD, for the English revision of present paper.

\section{References}

Afenyadu, D., King, K., McGrath, S., Oketch, H., Rogerson, C. \& Visser, K. (1999). Learning to compete: Education, training and enterprise in Ghana, Kenya and South Africa, Education Research Paper No. 42, Department for International Development (DFID). https:// ageconsearch.umn.edu/bitstream/12865/1/er990042
Awny, M. M., (2005), Technology Transfer and implementation processes in developing countries, International Journal of Technology Management (IJTM), Vol. 32 Nos. 1/2; pp. 213-220. https://doi. org/10.1504/IJTM.2005.006825

Bischoff, J., (2003). Technological conditions and issues in promoting integration of industrial activities at regional and global levels: Prospects and challenges of globalization and liberalization, Asian and Pacific Centre for Transfer of Technology.

Beukman, E., Steyn, H., (2011). Phasing Technology Transfer Projects for Sustainable Socio-Economic Development. South African Journal of Industrial Engineering November. Vol. 22, No. 2, pp. 40-53. http:// hdl.handle.net/10520/EJC46290

Dumont, E. L P., (2015). Remodeling technology transfer. Nature Nanotechnology, Vol. 10. pp. 184. Macmillan Publishers Ltd., www. nature.com/naturenanotechnology

Geisler, E., (2002). The metrics of technology evaluation: Where we stand and where we should go from here. International Journal of Technology Management. Vol. 24, No. 4, pp. 341-374. DOI: 10.1504/ IJTM.2002.003060, https://doi.org/10.1504/IJTM.2002.003060

Hermans J and Castiaux A., (2007) "Knowledge Creation through University-Industry Collaborative Research Projects”. The Electronic Journal of Knowledge Management. Volume 5 Issue 1, pp 43 - 54, available online at www.ejkm.com

Kondo, M., (2005), Networking for technology Acquisition and transfer; International Journal for Technology Management, Vol. 32, N's 1/2, pp. 154-175. Inderscience. https://doi.org/10.1504/IJTM.2005.006822

Kundu, N., Bhar, Ch., Pandurangan, V., (2015). Managing Technology Transfer. An Analysis of Intrinsic Factors. South Asian Journal $f$ Management. Vol. 22. No. 3, pp. 69-95.

Ofori, G., (1994a). Construction industry development: role of technology transfer, Construction. Management and Economics, Vol.12, pp. 379-392. https://doi.org/10.1080/01446199400000049

Olechowski, A., Eppinger, S. D., Nitin Joglekar, N., (2015). Technology Readiness Levels at 40: A Study of State-of-the-Art Use, Challenges, and Opportunities. Proceedings of Portland International Conference on Management of Engineering and Technology (PICMET), August 2015 http://ssrn.com/abstract=2588524

MIT Sloan School of Management, MIT Sloan School Working Paper 5127-15. Available at: https://www.researchgate.net/publication/297622762

Padilla-Pérez, R., (2008). A regional approach to study technology transfer through foreign direct investment: The electronics industry in two Mexican regions. Research Policy. Vol. 37, pp. 849-860. https:// ideas.repec.org/a/eee/respol/v37y2008i5p849-860.html 
Roy, R., Mehnen, J., (2008). Technology Transfer Academia to Industry, Studies in Computational Intelligence (SCI). Vol. 88, pp.263281. Springer-Verlag, Berlin. https://link.springer.com/chapter/10.1007/978-3-540-75771-9_12

Rosenberg, N., (1970). Economic Development and the Transfer of Technology: Some Historical Perspectives. Technology and Culture, Vol. 11. No. 4 550-575. The Johns Hopkins University Press and the Society for the History of Technology. URL: http://www.jstor.org/stable/3102691

Saad, M., Cicmil, S., Greenwood, M., (2002). Technology transfer projects in developing countries - Furthering the project management perspectives, International Journal of Project Management, 20, pp 617-625. http://dx.doi.org/10.1016/S0263-7863(02)00024-8

Shrestha G. B., Kumaraswamy, M.M., (1995). Problems in Technology Transfer vs. Potential for Technology Exchange: A Hong Kong Construction Perspective. Recovered from: http://www.irbnet.de/daten/iconda/CIB8957.pdf
Silanes Noticias (2011). Inaugura Silanes dos Nuevas Plantas en el Estado de México. Available at: https://www.silanes.com.mx/noticias/inaugurasilanes-dos-nuevas-plantas-en-el-estado-de-mexico.html, October 19th.

The World Bank. (2008). Global economic prospects: Technology diffusion in the developing world. Washington. The International Bank for Reconstruction and Development.

United Nations Conference on Trade and Development (1990). Recent trends in technology flows and their implication for development. United Nations, New York. http://hdl.handle.net/10986/6335

United Nations Department of Economic and Social Affairs, (2008). Climate Change: technology Development and Technology Transfer. Available at: https://sustainabledevelopment.un.org/content/documents/tec_technology_dev.pdf

Vega-González L. R., (2012). A Scorpion's Poison Antivenin R\&D+i Project Case from a Mexican Public University. Business and Economic Research, Vol. 2, No. 2, pp. 230-240. ISSN 2162-4860 http:// dx.doi.org/10.5296/ber.v2i2.2925 